\section{Rapid induction sequence with vecuronium: should we intubate after 60 or 90 seconds?}

Aline Boulanger MD FRCPC,

Jean-François Hardy MD FRCPC, Yves Lepage PhD
The purpose of the study was to determine intubating conditions after administration of either succinylcholine or vecuronium in a rapid induction sequence. Patients received either succinylcholine $1.5 \mathrm{mg} \cdot \mathrm{kg}^{-1}$ (Groups I and II) after d-tubocurarine 0.05 $\mathrm{mg} \cdot \mathrm{kg}^{-1}$ four minutes earlier, or vecuronium (Groups III and IV) in an initial dose of $0.01 \mathrm{mg} \cdot \mathrm{kg}^{-1}$ followed four minutes later by $0.1 \mathrm{mg} \cdot \mathrm{kg}^{-1}$. In Groups I and III an apnoeic delay of one minute was allowed before intubation whereas in Groups II and $V$ the delay was $90 \mathrm{sec}$. There was no significant difference in intubating conditions between Groups I and IV. Intubating conditions in Group III (vecuronium - delay of one minute) were statistically worse than in any of the three other groups. A delay of 90 sec after succinylcholine improved intubating conditions in male patients. Considering that intubating conditions obtained after 90 sec in patients given a priming sequence with vecuronium (Group IV) were not different from those obtained $60 \mathrm{sec}$ after succinylcholine (Group I), the authors conclude that vecuronium is an acceptable alternative for rapid tracheal intubation. In the doses used in this study, intubating conditions $60 \mathrm{sec}$ after vecuronium were unacceptable for rapid induction of anaesthesia.

\section{Key words}

NEUROMUSCULAR RELAXANTS: succinylcholine, vecuronium; PHARMACODYNAMICS: priming principle;

INTUBATION: tracheal;

MONITORING: neuromuscular junction, train-of-four.

From the Department of Anaesthesia, and the Department of Mathematics and Statistics, University of Montreal, Montreal, Quebec.

Address correspondence to: Dr. Jean-François Hardy, Department of Anaesthesia, Maisonneuve-Rosemont Hospital, 5415 boul. l'Assomption, Montreal, Quebec H1T 2M4.

This study was supported in part by a grant from the University of Montreal.
L'étude avait pour but de vérifier les conditions d'intubation lors d' une induction à séquence rapide utilisant la succinylcholine ou le vécuronium comme myorelaxant. Les patients des Groupes I et II recevaient un pré-traitement avec de la d-tubocurarine $0,05 \mathrm{mg} \cdot \mathrm{kg}^{-1}$ suivi quatre minutes plus tard de succinylcholine $1,5 \mathrm{mg} \cdot \mathrm{kg}^{-1}$. Les patients des Groupes III et IV recevaient une dose d' amorce de vécuronium de $0,01 \mathrm{mg} \cdot \mathrm{kg}^{-1}$, suivie quatre minutes plus tard d' une dose de $0,1 \mathrm{mg} \cdot \mathrm{kg}^{-1}$. Le délai entre l'administration du myorelaxant et l' intubation était de une minute dans les Groupes I et III, alors que dans les Groupes II et IV ce délai était de $90 \mathrm{sec}$. II n'y avait pas de différence statistiquement significative dans les conditions d'intubation entre les Groupes I et IV. Statistiquement, les moins bonnes conditions d' intubation se sont retrouvées chez les patients du Groupe III (vécuronium - délai d'une minute). Un délai de 90 sec après l'administration de la succinylcholine améliorait significativement les conditions d' iniubation chez les patients de sexe masculin. Etant donné que les conditions d'intubation des patients du groupe IV (vécruonium-délai de 90 sec) n'étaient pas différentes de celles des patients du Groupe I (succinylcholine-délai d' une minute), les auteurs concluent que le vécuronium constitue une alternative valable à la succinylcholine comme myorelaxant pour l'intubation d séquence rapide. Les conditions d' intubation $60 \mathrm{sec}$ après l'administration de vécuronium aux doses utilisées dans cette étude étaient inacceptables.

Rapid sequence induction of anaesthesia is a technique used in patients at risk of pulmonary aspiration to intubate the trachea rapidly and safely. Succinylcholine is the muscle relaxant used most frequently because of its rapid onset of action. However, succinylcholine has numerous side-effects which may lead to contraindications to its use. Pancuronium, in high doses, has been studied but its cardiovascular effects and prolonged duration of action make it unsuitable for use in a rapid induction sequence. The introduction of shorter-acting relaxants with fewer side-effects has stimulated several investigators to use these drugs for rapid tracheal intubation. Several studies 
have reported contradictory results using vecuronium in the rapid sequence technique. ${ }^{1-9}$ This may be for several reasons. First, most investigators have failed to reproduce the clinical conditions of rapid induction, since patients were already anaesthetized when the neuromuscular relaxant (NMR) was given. ${ }^{1-5}$ Furthermore, cricoid pressure was applied in only two studies. ${ }^{6-7}$ Second, the doses used for precurarization and paralysis varied above or below the clinically recommended dosages., ${ }^{4,5}$ Third, usually small numbers of patients have been studied. ${ }^{1-3,5-9}$ Fourth, intubating conditions may have been assessed by several investigators, decreasing the sensitivity of the measurement. ${ }^{9}$ Finally, intubation 90 sec after non-depolarizing NMR administration, as recommended by Savarese, ${ }^{10}$ was carried out in one study ${ }^{8}$ but without comparison with intubation after $60 \mathrm{sec}$

We undertook this study to compare intubating conditions after a standard rapid sequence induction with succinylcholine ${ }^{11}$ with those obtained with vecuronium, using the optimal priming sequence. ${ }^{12}$ Because of the slower onset of action of vecuronium we also wished to verify whether there was any advantage in intubating 90 $\mathrm{sec}$ rather than $60 \mathrm{sec}$ after administering the NMR.

\section{Methods}

This randomized double-blind study was approved by the Ethics Committee of Maisonneuve-Rosemont Hospital. Informed consent was obtained from all patients. One hundred and twenty-three patients, ASA physical status I-II, who were to undergo surgery necessitating tracheal intubation, were randomly allocated into four groups. Patients were excluded if there were potentially difficult intubating conditions, if they were taking medication known to interfere with neuromuscular relaxants, if they had neuromuscular or cardiac disease or if there were any contraindications to the use of succinylcholine. Most patients were premedicated with lorazepam 1-2 mg SL. After installation of ECG and non-invasive blood pressure monitoring, all patients received fentanyl $2 \mu \mathrm{g} \cdot \mathrm{kg}^{-1}$ and the precurarization or priming dose of NMR at time 0 . At one minute, 100 per cent oxygen was administered via face mask. At four minutes, thiopentone $5 \mathrm{mg} \cdot \mathrm{kg}^{-1}$ and

TABLE I Experimental groups

\begin{tabular}{llll}
\hline Group & $\begin{array}{l}\text { Precurarization } \\
\text { or priming } \\
\left(\mathrm{mg} \cdot \mathrm{kg}^{-1}\right)\end{array}$ & $\begin{array}{l}\text { Curarization } \\
\left(\mathrm{mg} \cdot \mathrm{kg}^{-1}\right)\end{array}$ & $\begin{array}{l}\text { Apnoea } \\
\text { (sec) }\end{array}$ \\
\hline I & d-tubocurarine 0.05 & succinylcholine 1.5 & 60 \\
II & d-tubocurarine 0.05 & succinylcholine 1.5 & 90 \\
III & vecuronium 0.01 & vecuronium 0.1 & 60 \\
IV & vecuronium 0.01 & vecuronium 0.1 & 90 \\
\hline
\end{tabular}

TABLE II Intubating conditions

\begin{tabular}{ll}
\hline Score & Intubating condirions \\
\hline 0 & $\begin{array}{l}\text { Vocal cords abducted; good visualization; no patient } \\
\text { movement }\end{array}$ \\
1 & $\begin{array}{l}\text { Vocal cords abducted; good visualization; diaphragmatic } \\
\text { movement with tracheal intubation }\end{array}$ \\
2 & $\begin{array}{l}\text { Vocal cords slightly adducted; fair visualization; coughing } \\
\text { on intubation of trachea } \\
\text { Vocal cords adducted; difficult visualization; gross } \\
\text { movement of the extremities and coughing with tracheal } \\
\text { intubation }\end{array}$ \\
\hline
\end{tabular}

the NMR were given as an IV bolus. Cricoid pressure was applied when patients lost consciousness. Direct laryngoscopy was performed and the trachea intubated with a cuffed tracheal tube $60 \mathrm{sec}$ (Groups I and III) or $90 \mathrm{sec}$ (Groups II and IV) after injection of the paralysing dose of NMR.

Patients in Groups I and II received a precurarizing dose of d-tubocurarine $0.05 \mathrm{mg} \cdot \mathrm{kg}^{-1}$, followed by a paralysing dose of succinylcholine $1.5 \mathrm{mg} \cdot \mathrm{kg}^{-1}$. Groups III and IV received a priming dose of vecuronium 0.01 $\mathrm{mg} \cdot \mathrm{kg}^{-1}$, followed by a paralysing dose of $0.1 \mathrm{mg} \cdot \mathrm{kg}^{-1}$ (Table I). Coded syringes were prepared by an assistant and contained either d-tubocurarine or vecuronium, adjusted with saline to a uniform volume of $3 \mathrm{ml}$ for the injection at time 0 , or succinylcholine or vecuronium, adjusted with saline to a uniform volume of $10 \mathrm{ml}$ for injection at four minutes. All intubations were performed by the same investigator (AB) who assessed intubating conditions according to the scale described by Fahey ${ }^{13}$ (Table II) and was unaware of the relaxant sequence. Neuromuscular blockade was monitored with a nerve stimulator (Digistim II - Neurotechnology) using trainsof-four (TOF) every ten seconds. The ulnar nerve was stimulated via surface electrodes and supramaximal stimulation was assessed by the method described by Kopman. ${ }^{14}$ The neuromuscular response was assessed visually by a second observer. Onset time was defined as the delay from injection of NMR until disappearance of TOF. Results are expressed as mean \pm standard deviation (SD). Chi-square and analysis of variance were used to compare the groups. A $P<0.05$ was considered significant.

\section{Results}

There were no statistically significant differences between groups with respect to age, gender, weight, ASA physical status, premedication, or type of surgery (Table III). Three patients were excluded from the study; one had not received medications according to the planned sequence, and in two others technical problems delayed 
TABLE III Study groups

\begin{tabular}{llllll}
\hline Groups & $I$ & $l l$ & $I I$ & $I V$ & $P$ \\
\hline Age (yr) & $34.7 \pm 12.4$ & $36.4 \pm 14.0$ & $37.3 \pm 16.1$ & $34.5 \pm 11.6$ & NS \\
Sex (F:M) & $19: 11$ & $18: 12$ & $18: 12$ & $22: 8$ & NS \\
$\begin{array}{l}\text { Weight (kg) } \\
\text { ASA (I:II) }\end{array}$ & $68.8 \pm 11.2$ & $64.9 \pm 12.2$ & $67.2 \pm 13.0$ & $63.3 \pm 14.4$ & NS \\
$\begin{array}{l}\text { Premedication } \\
\quad \text { (nothing: lorazepam) }\end{array}$ & $13: 17$ & $26: 4$ & $25: 5$ & $23: 7$ & NS \\
$\begin{array}{l}\text { Type of surgery: } \\
\text { - gynaecological }\end{array}$ & 9 & $17: 13$ & $17: 13$ & $15: 15$ & NS \\
- orthopaedic & 15 & 6 & 7 & & \\
- general & 5 & 13 & 17 & 11 & NS \\
- other & 1 & 5 & 2 & 4 & NS \\
\hline
\end{tabular}

NS: No statistical significant difference among groups.

TABLE IV Tracheal intubation scores

\begin{tabular}{lllll}
\hline & Groups & & \\
\cline { 2 - 5 } Intubation & $I$ & $I I$ & $I I$ & N \\
score & $($ Succ/60 sec $)$ & $($ Succ/90 sec $)$ & $($ Vec $60 \mathrm{sec})$ & $($ Vec/90 sec $)$ \\
\hline 0 & 19 & 27 & 13 & 21 \\
1 & 8 & 3 & 3 & 6 \\
2 & 3 & 0 & 10 & 1 \\
3 & 0 & 0 & 4 & 2 \\
\hline
\end{tabular}

intubation. Intubating conditions for the four groups are presented in Table IV.

Intubating conditions were significantly better in Group II (succinylcholine - delay of $90 \mathrm{sec}$ ) than in the other three groups. There was no statistically significant difference between Groups I and IV (succinylcholine delay of $60 \mathrm{sec}$ vs vecuronium - delay of $90 \mathrm{sec}$ ). The intubating conditions in Group III (vecuronium - delay of $60 \mathrm{sec}$ ) were significantly inferior to the other three groups, irrespective of gender.

Intubating conditions were independent of the patient's age or weight, but were significantly affected by gender (Table V). Overall, conditions were more favourable in females than males. Males in Group II had significantly better intubation scores than males in the other groups. In females of Group 1I, conditions were not different from those in Groups I and IV.

Onset time of neuromuscular blockade was significantly longer in the groups receiving vecuronium than in those receiving succinylcholine (Table VI).

\section{Discussion}

Rapid muscle relaxation and ideal intubating conditions are essential for a rapid sequence induction of anaesthesia. We were interested, above all, in the intubating conditions which we considered more important than the level of neuromuscular blockade, measured by ulnar nerve stimulation. Furthermore, this study attempted to reproduce faithfully the clinical practice of rapid sequence induction with regards to the drugs used and the application of cricoid pressure. All intubations were performed and scored by a single observer.

Intubating conditions after vecuronium, administered according to the priming principle and followed by an apnoeic period of $90 \mathrm{sec}$, were comparable with those after succinylcholine followed by a delay of $60 \mathrm{sec}$ before laryngoscopy, the "gold standard" for rapid tracheal intubation. Forty-six per cent of patients intubated $60 \mathrm{sec}$ after administration of identical doses of vecuronium had intubating scorcs of two or three. We consider this unacceptable for a rapid induction regimen. ${ }^{\text {IS }}$

In Group IV it is interesting to note that satisfactory intubating conditions were obtained before complete abolition of muscle contractions. This agrees with the

TABLE V Tracheal intubation score and gender

\begin{tabular}{|c|c|c|c|c|c|c|c|c|c|c|}
\hline \multirow{2}{*}{$\begin{array}{l}\text { Intubation } \\
\text { score }\end{array}$} & \multicolumn{4}{|c|}{ Women } & \multicolumn{4}{|c|}{ Men } & \multirow{2}{*}{$\begin{array}{l}\text { Total } \\
(F)\end{array}$} & \multirow{2}{*}{$\begin{array}{l}\text { Total } \\
\text { (M) }\end{array}$} \\
\hline & 1 & 2 & 3 & 4 & $I$ & 2 & 3 & 4 & & \\
\hline 0 & 13 & 15 & 12 & 19 & 6 & 12 & 1 & 2 & 59 & 21 \\
\hline 1 & 5 & 3 & 1 & 3 & 3 & 0 & 2 & 3 & 12 & 8 \\
\hline 2 & 1 & 0 & 3 & 0 & 2 & 0 & 7 & 1 & 4 & 10 \\
\hline 3 & 0 & 0 & 2 & 0 & 0 & 0 & 2 & 2 & 2 & 4 \\
\hline
\end{tabular}


TABLE VI Onset time of neuromuscular blockade

\begin{tabular}{lllll}
\hline Groups & 1 & 2 & 3 & 4 \\
\hline
\end{tabular}

Time (sec) $\quad 56.5 \pm 16.6 \quad 60.4 \pm 23.1 \quad 149.4 \pm 43.9 \quad 132.8 \pm 39.3$

report by Fahey ${ }^{13}$ and is further supported by Chauvin ${ }^{16}$ who showed that vecuronium $0.1 \mathrm{mg} \cdot \mathrm{kg}^{-1}$ produced diaphragmatic paralysis in $1.6 \mathrm{~min}$ while paralysis of the adductor pollicis took $2.5 \mathrm{~min}$. This study supports the concept that "observation of intubation conditions constitutes a more clinically relevant end-point than the measurement of adductor pollicis response."17

A similar dose of NMR (in $\mathrm{mg} \cdot \mathrm{kg}^{-1}$ ) produced overall better intubating conditions in females. In males, a delay of $90 \mathrm{sec}$ after succinylcholine (Group II) significantly improved intubating conditions compared with the usual $60 \mathrm{sec}$ delay (Group I). Men in Group IV had similar $(P>$ 0.05 ) intubating conditions to men in Group I, the "gold standard" for rapid sequence induction of anaesthesia. It should be noted (Table V) that two males in Group I and three males in Group IV had unacceptable conditions for rapid tracheal intubation by our standards (intubating scores of two or three). Further study appears warranted to confirm these findings before recommending a change in accepted practice.

We used an interval of four minutes between the precurarizing and final dose of vecuronium as suggested by Taboada et al. ${ }^{12}$ This agrees with the results of Baumgarten $^{9}$ and Naguib $^{18}$ and with the recommendations by Donati. ${ }^{17} \mathrm{We}$ also used the "ideal" priming and paralyzing doses proposed by Taboada et al., 12 i.e., 0.01 $\mathrm{mg} \cdot \mathrm{kg}^{-1}$ and $0.1 \mathrm{mg} \cdot \mathrm{kg}^{-1}$ of vecuronium. Donati ${ }^{17}$ recommends the use of smaller priming doses, 0.005 $\mathrm{mg} \cdot \mathrm{kg}^{-1}$ of vecuronium, based on a report of respiratory function tests performed after priming with nondepolarizing neuromuscular relaxants. ${ }^{19}$ This study showed that vecuronium in doses of $0.005 \mathrm{mg} \cdot \mathrm{kg}^{-1}$ and $0.01 \mathrm{mg} \cdot \mathrm{kg}^{-1}$ significantly reduced the TOF ratio and this reduction was greater in those patients who had received doses of $0.01 \mathrm{mg} \cdot \mathrm{kg}^{-1}$. Vecuronium 0.01 $\mathrm{mg} \cdot \mathrm{kg}^{-1}$ significantly reduced peak expiratory flow rate from 475 to $460 \mathrm{~L} \cdot \mathrm{min}^{-1}$ in these patients but the respiratory rate, vital capacity, and inspiratory force remained unchanged. Also, the signs and symptoms of curarization were no different between the two groups. Considering the above and given that the dose of 0.005 $\mathrm{mg} \cdot \mathrm{kg}^{-1}$ was found to be less effective clinically than $0.01 \mathrm{mg} \cdot \mathrm{kg}^{-1}, 1.7 .12$ we chose to administer a priming dose of $0.01 \mathrm{mg} \cdot \mathrm{kg}^{-1}$ vecuronium. Priming doses greater than $0.01 \mathrm{mg} \cdot \mathrm{kg}^{-1}$ offer no advantage, may produce important symptoms of curarization ${ }^{12.19}$ and, finally, render the patient vulnerable to pulmonary aspiration. ${ }^{20}$
Savarese $^{10}$ suggested a delay of $90 \mathrm{sec}$ apnoea when using a rapid induction technique with a non-depolarizing neuromuscular relaxant. The delay of $90 \mathrm{sec}$ may lead to the possibility of hypoxaemia and redistribution of induction agents. We measured oxygen saturation in several patients and did not observe desaturation after 60 or $90 \mathrm{sec}$ of apnoea. Preoxygenation for three minutes allows arterial oxygen saturation to be maintained greater than 95 per cent for up to eight minutes of apnoea in the normal patient, ${ }^{21}$ and for $2 \mathrm{~min} 20 \mathrm{sec}$ in the pregnant patient. ${ }^{6}$ We did not have ability to evaluate the redistribution of anaesthetic induction agents but, given the doses used, we did not feel that supplementation was necessary at the time of intubation.

In conclusion, similar intubating conditions for a rapid sequence induction of anaesthesia may be achieved with the use of vecuronium or succinylcholine in the doses described in this study, provided a longer period of time is allowed before laryngoscopy when vecuronium is chosen to facilitate tracheal intubation. However, the optimal dosage of NMR and/or ideal delay before intubation may have to be redefined in men, since a clinically significant proportion of them presented unacceptable intubating conditions despite the use of generally accepted regimens for rapid sequence induction of anaesthesia.

\section{Acknowledgement}

We thank Mme Sylvie Le Breux for her expert secretarial assistance.

\section{References}

1 Martin C, Bonneru JJ, Brun JP, Albanese J, Gouin $F$. Vecuronium or suxamethonium for rapid sequence intubation. Which is better? Br J Anaesth 1987; 57: 1240-4.

2 Brady MM, Mirakhur RK, Clarke RSJ, Gibson FM. Administration of atracurium or vecuronium in divided doses does not accelerate their onset of action. Anesthesiology 1987; 67: A347.

3 Mehta MP, Gergis SD, Sokoll MD. Accelerated onset of pancuronium, atracurium, and vecuronium. A comparison to succinylcholinc. Anesth Analg 1986; 65: S97.

4 Foldes $F F$. Rapid tracheal intubation with nondepolarizing neuromuscular blocking drugs: the priming principle. Anesthesiology 1984; 61: A294.

5 Schwarz S, llias W, Lackner F, Mayrhofer O. Foldes $F F$. Rapid tracheal intubation with vecuronium: the priming principle. Anesthesiology 1985; 61: 388-91.

6 Tessen JH, Johnson TD, Skjonsby BS, Kubicek MF, Joyce $T H$. Evaluation of vecuronium for rapid sequence induction in patients undergoing Cesarean section. Anesthesiology 1987; 67: A452. 
7 Kunjappan VE, Brown EM, Alexander GD. Rapid sequence induction using vecuronium. Anesth Analg 1986; 65: 503-6.

8 Sosis $M$, Stiner $A E$, Marr $A T$. Does the priming principle work? Anesthesiology 1985; 63: A340.

9 Baumgarten RK, Carter CE, Reynolds WJ, Brown $J L, D e$ Vera $H V$. Priming with nondepolarizing relaxants for rapid tracheal intubation: a double blind evaluation. Can J Anaesth 1988; 35: 5-11.

10 Savarese JJ. Clinical relaxation: current controversy. Can J Anaesth 1986; 33: S1-S4

11 Gibbs $C P$, Modell $J H$. Aspiration pneumonitis. In: Miller RD (Ed.). Anesthesia, 2nd ed., New York: Churchill Livingstone Inc., 1986: 2023-50.

12 Taboada JA, Rupp SM, Miller RD. Refining the priming principle for vecuronium during rapid sequence. Anesthesiology 1986; 64: 243-7.

13 Fahey MR, Morris RB, Miller RD, Sohn YJ, Cronnelly R, Gencarelli $P$. Clinical pharmacology of ORG NC 45 (Norcuron ${ }^{(}$). A new nondepolarizing muscle relaxant. Anesthesiology 1981; 55: 6-11.

14 Kopman AF, Lawson D. Milliamperage requirements for supramaximal stimulation of the ulnar nerve with surface electrodes. Anesthesiology 1984; 61: 83-5.

15 Hardy $J F$. Large volume gastroesophageal reflux: a rationale for risk reduction in the perioperative period. Can J Anaesth 1988; 35: 162-73.

16 Chauvin $M$, Lebrault $C$, Duvaldestin $P$. The neuromuscular blocking effect of vecuronium on the human diaphragm. Anesth Analg 1987; 66: 117-22.

17 Donati $F$. The priming saga: where do we stand now? Can J Anaesth 1988; 35: 1-4.

18 Naguib $M$, Gyasi $H K$, Abdulatif $M$, Absood $G H$. Rapid tracheal intubation with atracurium - a comparison of priming intervals. Can J Anaesth 1986; 33: 150-5.

19 Engback J, Howardy-Hansen P, Ording H, VibyMogensen J. Precurarization with vecuronium and pancuronium in awake, healthy volunteers: the influence on neuromuscular transmission and pulmonary function. Acta Anaesthesiol Scand 1985; 29: 117-20.

20 Musich J, Walts LF. Pulmonary aspiration after a priming dose of vecuronium. Anesthesiology 1986; 64: 517.

21 Gambee AM, Hertzka RE, Fisher DM. Preoxygenation techniques: comparison of three minutes and four breaths. Anesth Analg 1987; 66: 468-70. 